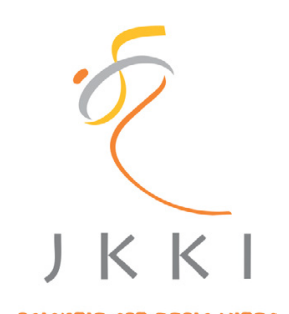

SCIEMTIF EST BASIC VITAE

\section{Jurnal Kedokteran dan Kesehatan Indonesia}

\author{
Indonesian Journal of Medicine and Health
}

Journal homepage : www.journal.uii.ac.id/index.php/JKKI

\title{
The effect of fasting to the quality of spermatozoa in adult male rattus norvegicus
}

\author{
Nur Azizah Hafaz*1, Ageng Brahmadhi², Prima Maharani Putri ${ }^{1}$ \\ ${ }^{1}$ Faculty of Medicine, Muhammadiyah University of Purwokerto, Central Java, Indonesia \\ ${ }^{2}$ Department of Histology, Faculty of Medicine, Muhammadiyah University of Purwokerto, Central Java, Indonesia
}

Original Article

\begin{tabular}{|c|c|}
\hline & ABSTRACT \\
\hline ARTICLE INFO & Backround: Oxidative stress contributes in male infertility as a causative \\
\hline $\begin{array}{l}\text { Keywords: } \\
\text { stress, } \\
\text { fasting, } \\
\text { sperm motility, } \\
\text { sperm viability, } \\
\text { sperm morphology }\end{array}$ & $\begin{array}{l}\text { cause oxidative stress. Furthermore, oxidative stress would increase ROS } \\
\text { concentration. The increase of ROS contributes to infertility and decrease } \\
\text { of testis weight. A lot of studies had been conducted on more than } 24 \text { hours } \\
\text { fasting which leads to reducing sperms quantity, volume, and motility. In } \\
\text { the other hand studies on fasting for less than } 24 \text { hours are still limited: }\end{array}$ \\
\hline $\begin{array}{l}\text { *Corresponding author: } \\
\text { zizahmathlover@gmail.com } \\
\end{array}$ & $\begin{array}{l}\text { therefore study to evaluate the effect of stress caused by fasting for less } \\
\text { than } 24 \text { hours to the quality of spermatozoa in adult male mice is needed. }\end{array}$ \\
\hline $\begin{array}{l}\text { DOI : } 10.20885 / J K K I . V o l 8 . I s s 2 . a r t 3 \\
\text { History: } \\
\text { Received: March 8, } 2017 \\
\text { Accepted: May 18, } 2017\end{array}$ & $\begin{array}{l}\text { Objective: To determine the effect of } 10 \text { hours and } 12 \text { hours fasting to } \\
\text { the quality of spermatozoa which included its motility, viability, and } \\
\text { morphology in adult male mice. }\end{array}$ \\
\hline & $\begin{array}{l}\text { Methods: This study is an experimental research. Three months old male } \\
\text { Wistar mice were divided into } 3 \text { groups, in which each group contained } \\
10 \text { mice. Group } 1 \text { was the control group, group } 2 \text { was treated with } 10 \\
\text { hours fasting for } 14 \text { days, and group } 3 \text { was treated with } 12 \text { hours fasting } \\
\text { for } 14 \text { days. After the intervention, their sperm motility, viability, and } \\
\text { morphology were observed. Motility and morphology data were analyzed } \\
\text { using One-Way ANOVA test, whereas the viability data was analyzed using } \\
\text { Kruskal. } \\
\text { Results: The sperm's motility, viability, and morphology of the control } \\
\text { group were different from the two intervention groups (p }<0,05 \text { ). Control } \\
\text { group had significant difference compared to the group of } 10 \text { hours } \\
\text { fasting and group of } 12 \text { hours fasting (p }<0,05) \text {. There was no significant } \\
\text { difference between treatment groups (p }>0,05) \text {. } \\
\text { Conclusion: } 10 \text { hours and } 12 \text { hours fasting affect the quality of sperm in } \\
\text { adult male mice. }\end{array}$ \\
\hline
\end{tabular}

Latar Belakang: Stres oksidatif berperan dalam faktor penyebab idiopatik infertilitas pada laki-laki. Puasa merupakan salah satu bentuk stres fisik yang juga mengakibatkan terjadinya stres oksidatif. Stres oksidatif dapat mengakibatkan peningkatan kadar ROS. Peningkatan kadar ROS menyebabkan terjadinya infertilitas dan penurunan berat testis. Puasa lebih dari 24 jam telah banyak diteliti yang menunjukkan penurunan jumlah, volume dan motilitas sperma. Sedangkan puasa kurang dari 24 jam jarang diteliti, sehingga perlu dilakukan penelitian untuk mengevaluasi efek dari stres dengan perlakuan puasa kurang dari 24 jam pada kualitas spermatozoa tikus jantan.

Tujuan Penelitian: Untuk mengetahui efek pemberian stres melalui perlakuan puasa 10 jam dan puasa 12 jam terhadap kualitas spermatozoa meliputi motilitas, viabilitas dan morfologi sperma pada tikus jantan dewasa. 
Metode: Penelitian ini merupakan penelitian laboratorium. Sebanyak 30 ekor tikus putih yang memenuhi kriteria inklusi: tikus jantan, galur wistar, usia 3 bulan, dengan berat badan $200-250$ g dibagi menjadi 3 kelompok dengan tiap kelompok berjumlah 10 ekor tikus. Kelompok 1 kontrol diberi makan dan minum ad libitum, kelompok 2 perlakuan puasa 10 jam dan kelompok 3 perlakuan puasa 12 jam selama 14 hari. Setelah perlakuan, dilakukan pengamatan motilitas, viabilitas dan morfologi sperma. Data motilitas dan morfologi dianalisis menggunakan One Way Anova, sedangkan viabilitas menggunakan uji non parametrik Kruskal Wallis. Hasil: Motilitas, viabilitas dan morfologi sperma kelompok kontrol berbeda dengan kedua kelompok perlakuan $(p<0,05)$. Kelompok kontrol memiliki perbedaan yang signifikan dengan kelompok puasa 10 jam dan 12 jam $(p<0,05)$. Namun, antara kelompok puasa 10 jam dengan puasa 12 jam tidak ada perbedaan yang signifikan $(p>0,05)$.

Kesimpulan: Pemberian stres melalui perlakuan puasa 10 jam dan puasa 12 jam selama 14 hari mempengaruhi kualitas spermatozoa pada tikus jantan dewasa.

\section{INTRODUCTION}

Infertility is a health concern across the globe. According to American Society for Reproduction Medicine, 1/3 of infertility causes is related to female, $1 / 3$ is related to male, and the rest is related to the combination of both. ${ }^{1}$ Male infertility is related to a lot of factors, for instance, anatomical abnormalities, endocrinopathy, immunology, gene mutation, radiation, chemotherapy, ejaculation dysfunction, and environmental factors. ${ }^{2} 25 \%$ of the cause of infertility in a male are idiopathic. In which oxidative stress is thought to contribute in the pathomechanism of idiopathic male infertility. ${ }^{3}$

Fasting is a kind of physical stress. It can also cause oxidative stress. ${ }^{4}$ Oxidative stress occurs due to the imbalance of pro-oxidant and antioxidant, causing an increase of Reactive Oxygen Species (ROS). ${ }^{5}$ Mammals testicular membranes contain a lot of polyunsaturated fat and are very susceptible to oxidative stress, hence an increase of ROS concentration would be able to cause infertility and testicular damage. ${ }^{6}$

Fasting in animal models would induce ketogenesis which would influence the condition of redox cells, alter metabolic pathway, as well as the cellular process like stress resistance, lipolysis, and ROS formation due to the decrease of pyridine nucleotides like NADH or NADPH. ${ }^{7,8}$ Fasting would also affect gonadotropin hormones as well as testosterone through hypothalamuspituitary-testis pathway or through a direct effect on testis which would affect spermatogenesis. ${ }^{9}$

A lot of study on the effect of chronic fasting had been conducted. Those studies showed that 12 hours/day and 24 hours/day fasting for 65 days caused a decrease of testis weight, sperm count, sperm volume, sperm motility, FSH concentration, LH concentration, and testosterone concentration in male Albino rats. ${ }^{10}$ Studies about the effect of fasting for less than 24 hours are still rarely conducted. Because of these reasons, a study to evaluate the effect of fasting for less than 24 hours on the quality of spermatozoa of male rats is needed.

\section{METHODS}

This research is a laboratory experimental research with post test only with control group study design. As much as 30 white rats were included in this experiment, which fulfilled the inclusion criteria: male, Wistar rats, within the age of 3 months, weighing between $200-250$ g. Rats were divided into 3 groups, in which each group contained 10 rats. All rats were acclimatized for 1 week in a dark-bright area (12:12 hours) and were fed ad libitum. After acclimatization, the first group (I) was fed ad libitum, a second group (II) was intervened with 10 hours / day fasting, and the third group (III) was intervened with 12 hours/day fasting. Fasting was done for 14 days. Rat is a nocturnal animal, in which they are more active at night rather than day, hence the intervention was done during the night. ${ }^{11}$

Data collection was done at the end of the intervention. Rat models were anesthetized using chloroform $0,5 \mathrm{ml} /$ individual, then they were decapitated using minor surgery set. Cauda epididymis was separated and inserted into the petri dish containing $1 \mathrm{ml}$ of $\mathrm{NaCl} 0,9$ $\%$ solution. Cauda epididymis was sliced into 
smaller size using a scissor until finely chopped, then stirred well until spermatozoa suspensions were formed. Spermatozoa suspensions were used to evaluate the quality of spermatozoa which included sperm motility, viability, and morphology of each rat.

\section{Sperm Motility}

Motility was observed from the movement of the sperm in the microscope, it was measured whether the movement was progressive, nonprogressive, or immobile. The progressive movement was defined as the active, fast, and straight movement. The non-progressive movement was defined as less active and slow movement. Immobile was defined as imotyl sperms. $^{12}$

One drop of spermatozoa sperm was put onto the object glass and covered with cover glass. The observation was done using a microscope at 400x magnification. The number of progressive, non-progressive, and imotyl sperm was counted. The observation was done in 200 sperm cells within 10 different fields of view. ${ }^{12,13}$ Progressive moving sperm was counted in percentage. ${ }^{14}$

\section{Sperm Viability}

Sperm viability was observed by its color, in which live sperm was translucent and dead sperm was red. ${ }^{12}$ One drop of spermatozoa suspension $(40 \mu \mathrm{L})$ was put onto object glass, then $10 \mu \mathrm{L}$ Eosin-Y 0,5 \% was added, and then mixed. The mixture was covered with cover glass. The observation was done using a microscope at 400x magnification. Live sperm cells were translucent and dead sperm cells were red in color. The observation was done in 200 sperm cells within 10 different fields of view randomly. ${ }^{12,13}$ The percentage of sperm viability was counted by measuring the number of living sperm cells divided by the number of total sperm cells being observed, times $100 \%$.

\section{Sperm Morphology}

Sperm morphology was classified into two different types, which are normal and abnormal sperm (head, midpiece, and tail). ${ }^{12}$
One drop of spermatozoa suspension was put onto object glass, and then a smear was made using a tip of a different slide in 450 angle and then dried. After the preparation was dry, methanol was added for 5 minutes to fix the preparation. Giemsa was added for 10-15 minutes, and then it was washed using running water and dried once more. After the preparations were dried, an observation was done using Opti Lab in the microscope with 400x magnification. The observation was done in 200 sperm cells within 10 different fields of view. ${ }^{12,13}$ The percentage of sperm morphology was counted by measuring the number of normal sperm divided with a total number of sperm cells being observed and times $100 \%$.

Data of sperm motility was analyzed using One-Way ANOVA, continued with post hoc LSD, while data of sperm viability and morphology was analyzed using Kruskal-Wallis continued with post hoc Mann-Whitney U.

\section{RESULTS}

The results of data analysis showed that there was the statistically significant difference between control and intervention groups. Control groups showed larger mean motility rate when compared to the intervention group. The mean of sperm motility between the control group and fasting group for 10 and 12 hours showed statistically significant difference $(\mathrm{p}<0,05)$, however, there was no statistically significant difference between the intervention group ( $p$ > 0,05 ) on Figure 1.

\section{Sperm Viability}

The results of observation showed that there was statistically significant difference between control and intervention group. Control group had the highest sperm viability compared to an intervention group. Control group had the statistically significant difference of sperm viability when compared to an intervention group $(\mathrm{p}<0,05)$. However, there was no statistically significant difference in sperm viability between 10 hours fasting group and 12 hours fasting group ( $p>0,05)$ on Figure 2 . 


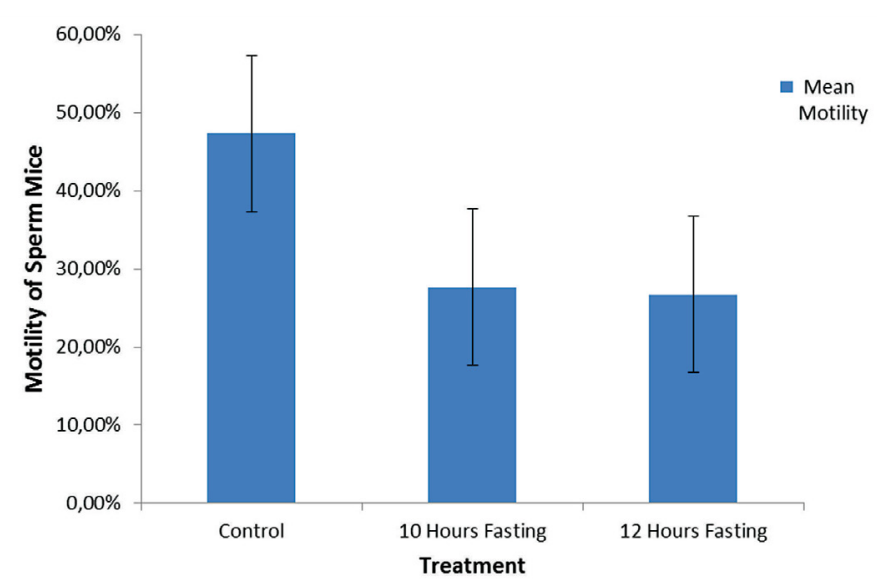

Figure 1. Sperm motility. Control group 47,34 \%, 10 hours of fasting group $27,62 \%$ and 12 hours of fasting group $26,73 \%$.

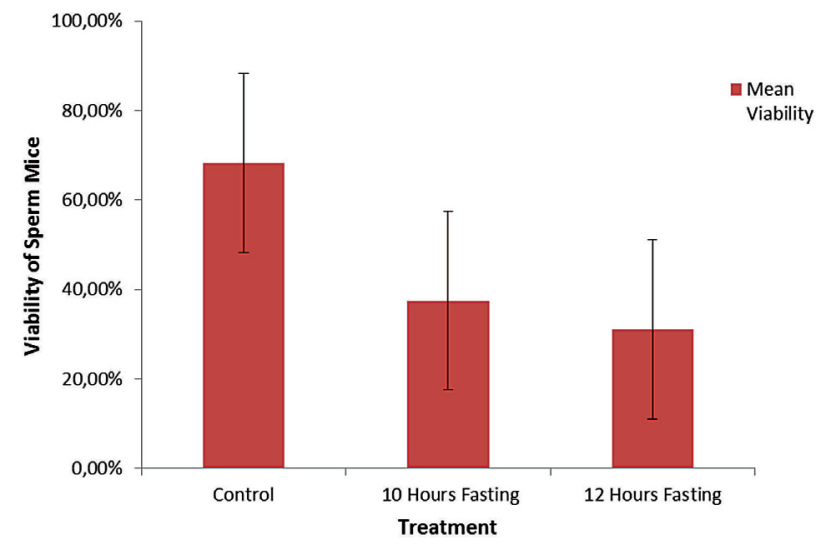

Figure 2. Sperm viability. Control group 53,43\%, 10 hours of fasting group $34,43 \%$ and 12 hours of fasting group 31,23\%.

Microscopical observation using Eosin-Y translucent in color, while dead sperm was red $0,5 \%$ staining showed that live sperm was in color (Figure 3).

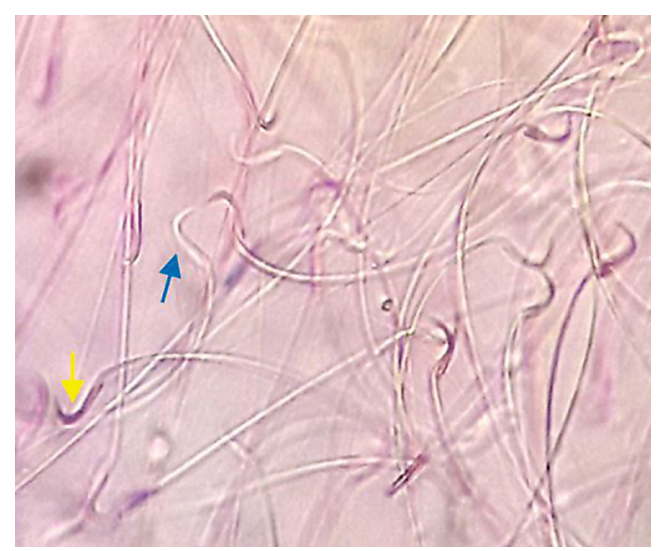

Figure 3. Sperm viability using Eosin-Y 0,5 \% staining. Yellow arrow showed dead sperm was red in color, Blue arrow showed living sperm was translucent.

\section{Sperm Morphology}

The results of observation showed that there was the statistically significant difference of sperm morphology between control and intervention groups. Normal sperm morphology was found at the most in control group. There 
was the statistically significant difference of normal sperm morphology between the control group and both intervention groups $(\mathrm{p}<0,05)$. However, this study did not find any statistically significant difference of normal sperm morphology between 10 hours fasting group and 12 hours fasting group $(p>0,05)$ on Figure 4.

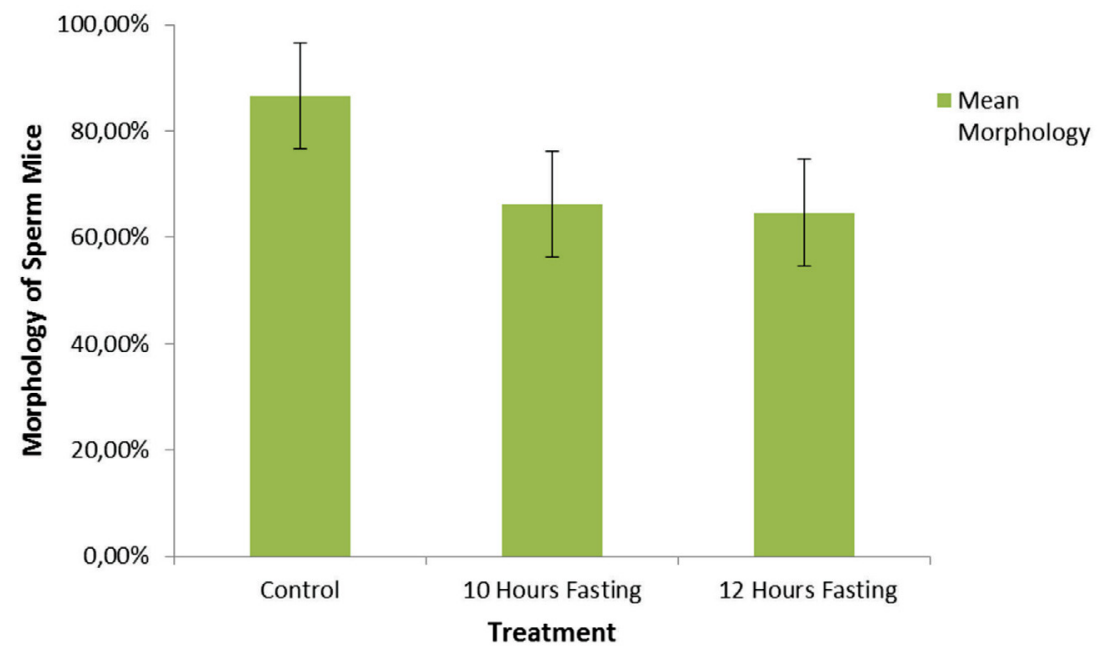

Figure 4. Normal sperm morphology in control group was $86,67 \%, 10$ hours of fasting group was $66,22 \%$ and 12 hours of fasting group was $64,65 \%$.

The results from sperm morphology observation in control group showed normal head, mid-piece, and tail. The sperm morphology of both intervention groups showed more abnormal sperm compared to control group.

The morphological abnormalities found in this study included head without mid-piece, abnormal head, tail without the head, and curly tail. (Figure 5).
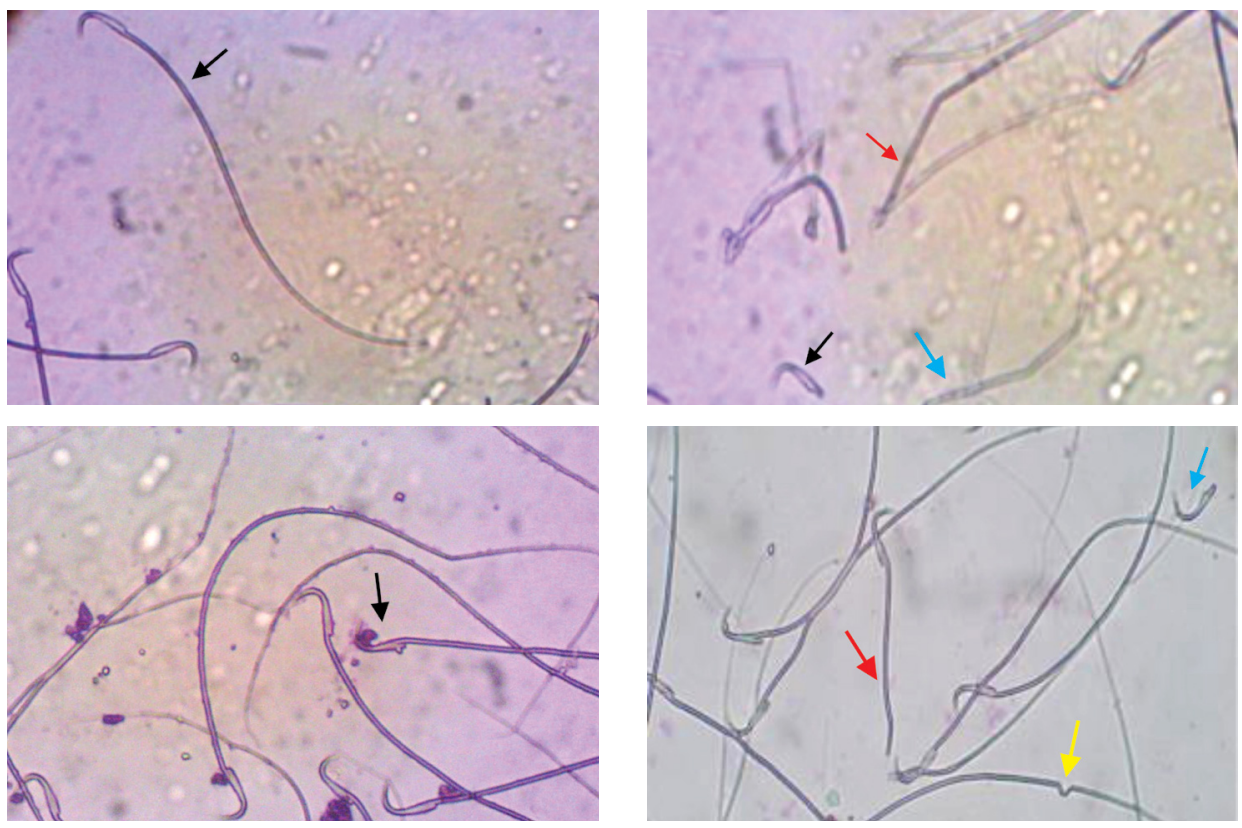

Figure 5. Sperm morphology in Giemsa staining. A : control (normal head, mid piece and tail); B : fasting 10 hours (black arrow) head without tail, (red arrow) detached tail, (blue arrow) tail without head; C : 12 hours fasting (abnormal head); D : 12 hours fasting (red arrow) detached tail, (yellow arrow) curly tail, (blue arrow) head without tail. 


\section{Data Analysis}

The results from One Way ANOVA analysis showed the significant difference of sperm motility between control and intervention group ( $p=0,00 ; \alpha=0,05)$. LSD test showed the significant difference between control group with 10 hours fasting group and 12 hours fasting group $(p<0,05)$. However, there was no significant difference between 10 hours fasting group and 12 hours fasting group ( $p$ > $0,05)$. Viability and morphology were analyzed using nonparametric test Kruskal-Wallis, results showed that there was significant difference between intervention and control group $(\mathrm{p}=$ $0,00 ; \alpha=0,05)$. This showed that there was association between stress which was induced by fasting towards the viability and morphology of sperm cells. The analysis was continued with Mann-Whitney U, which showed that the viability of 10 hours and 12 hours fasting groups were significantly different compared to control group $(\mathrm{p}<0,05)$. However, there was no statistically significant difference between the intervention groups $(\mathrm{p}>0,05)$.

\section{DISCUSSION}

Sperm motility was measured by the movement of the sperm cells. Spermatozoa that has good motility will have active and forward movement, while sperm cells that have bad motility will have slow, curvaceous, or circling movement..$^{15}$ Sperm viability was measured by the color of the sperm cells, in which living sperm cells would be translucent in color and dead sperm cells would be red in color. ${ }^{12}$ Normal spermatozoa quality will have a complete morphological characteristic, for instance: normal head shape and size, attached acrosome, straight or non-crooked midpiece with no residual body, its tail (flagella) is straight, not crooked, curvy, curly, or detached. ${ }^{16}$

The results of this study showed significant difference of sperm motility, viability, and morphology between control and intervention groups. The average of sperm motility, viability, and morphology in the control group was found better than 10 hours fasting and 12 hours fasting group. Sperm motility in 10 hours and 12 hours fasting group showed that a lot of the sperm cells were moving slowly, circling, curvaceous, back and forth, or even imotyl. While in cotrol group, most of the sperm moved fast and straight. The sperm morphology in control group had more sperm cells with normal cell morphology, including normal head, midpiece, and tail. The intervention groups showed more abnormal morphology, including: heads without tails, tails without heads, detached tails, abnormal heads, and curly tails.

These results are in accordance with previous research which found that 12 hours fasting for 30 days caused an alteration of sperm morphology, incuding: dull and slow sperm movement, imotyl, or reversed movement. The number of living sperm cells in the intervention group was 26,98 , which was half from the control group that had 50,33 living sperm cells. Sperm morphology, including detached heads and curving tails, in intervention group was greater in number when compared to control. ${ }^{19}$

Another research also showed a decrease of sperm motility in the group that was intervened with 50 days of stress. ${ }^{13}$

Similar results was also found in previous research where sperm viability was significantly reduced in the stress-induced group when compared to control. ${ }^{17}$

Another research reported larger abnormal sperm morphology in restricted-diet group when compared to control. ${ }^{18}$ Another research showed that stress induction could affect sperm viability and morphology when compared to control. The groups who were intervened with stress had more abnormal sperm compared to control. The abnormalities were found in the form of rounded heads, needle heads, detached tails, and crooked tails. ${ }^{14}$

Another research also found that $60 \%$ calory restriction and heat intervention $\left(22^{\circ} \mathrm{C}\right.$ and $38^{\circ} \mathrm{C}$ ) for 9 weeks in rat models could decrease sperm motility and morphology of intervention group, even though there was no significant 
difference in sperm viability between control and intervention groups. In addition to that, the sperm viability between control and intervention group was within the same range. The average viability of 12 hours fasting group was 95,2\% and 24 hours fasting group was $96,2 \%$, while the control group was $98,0 \%{ }^{6}$

Another research showed that sperm motility in high-fat diet restriction group was different with control and high-fat diet group, however, there was no statistically significant difference in term of sperm viability between the highfat diet restriction group and control. ${ }^{19}$ These findings are in accordance with a theory which stated that the male infertility factors can be affected by sperm concentration and or sperm motility and or sperm morphology in one or two sample analysis. ${ }^{20}$ Sperm motility is an important and the main indicator for fertility. ${ }^{3}$ Hence, sperm viability is not the main indicator used to measure sperm quality.

In accordance with a theory which stated that fasting can cause oxidative stress, the ROS concentration will increase as well. Oxidative stress could damage DNA integrity of spermatozoa's nucleus, thus inducing apoptosis. Apoptosis is a physiologic programmed cell death which is determined by the changes of cell morphology and biochemical. Apoptosis is regulated by both intrinsic and extrinsic factors, and it can be stimulated by various stimuli. ${ }^{21}$ The increase of ROS concentration caused by oxidative stress would damage mitochondrial membrane and induce apoptosis which would ultimately affect spermatozoa motility. ${ }^{21,22}$

Death spermatozoa cells would absorb color from staining due to the damage in its plasma membrane, causing an alteration of its sodium pump thus affecting its ability to regulate the input and output of substances from and into cells. Because of these reasons, eosin staining could enter the cell and stay inside the cells, thus produce color for spermatozoa into red or even darker, especially on the head of the spermatozoa. ${ }^{14}$ The death of spermatozoa could be caused by free radicals that could affect cell death. ${ }^{15}$

Sperm abnormality occurred due to oxidative stress that was induced by fasting. Oxidative stress acted as a mediator of plasma membrane damage, hence decreasing the quality of spermatozoa. The damage of membrane plasma through oxidative stress would cause a decrease in spermatozoa function. Oxidative stress would induce DNA damage and accelerate apoptosis of epithelial germinal cells. This condition would cause a decrease in spermatozoa number and alter its morphology. ${ }^{23}$

The increase of ROS concentration in cell membrane would trigger a chain of chemical reaction called lipid peroxidation, which would decrease the fluidity and activity of ion and enzymes of the membrane. This condition would inhibit the normal mechanism of the cells which would support fertilization. Thus, lipid peroxidation due to the increase of ROS concentration contributes as a factor that causes alteration in spermatozoa morphology. ${ }^{9,20}$

\section{CONCLUSION}

Stress intervention, in the form of $>24$ hours fasting (10 and 12 hours fasting) for 14 days, decreased the quality of spermatozoa in terms of its motility, viability, and morphology in adult male rat models.

\section{ACKNOWLEDGEMENT}

To Fakulty of Medicine UMP who had to support the making of this article. To Fakultas Kedokteran Universitas Jendral Soedirman who had allowed the utilization of its Research Laboratory for this study until the finish.

\section{REFFERENCE}

1. Saki G, Rahim F, Alizadeh K. Effect of forced swimming stress on count, motility and fertilization capacity of the sperm in adult rats. Journal of Human Reproductive Sciences. 2009;2(2):72-5.

2. Bhongade MB, Prasad S, Jiloha RC, Ray PC, Mohapatra S, Koner BC. Effect of psychological stress on fertility hormones and 
seminal quality in male partners of infertile couples. Andrologia. 2014;47(3):1-7.

3. Badade ZG, More K, Narshetty J. Oxidative stress adversely affects spermatogenesis in male infertility. Biomedical Research. 2011;22(3):323-8.

4. Wresdiyati T, Astawan M, Fithriani D, Ketut Mudite Adnyane I, Novelina S, Saptina A. Pengaruh $\alpha$-tokoferol terhadap profil superoksida dismutase dan malondialdehida pada jaringan hati tikus di bawah kondisi stres. Jurnal Veteriner. 2007;202-9.

5. Srinivasan S, Wankhar W, Rathinasamy S, Rajan R. Neuroprotective effects of indigofera tinctoria on noise stress affected wistar albino rat brain. Journal of Applied Pharmaceutical Science. 2015;5(6):05865.

6. Aydilek N, Varisli 0, Kocyigit A, Taskin A, Kaya MS. Effect of dietary restriction on sperm characteristic and oxidative status on testicular tissue In young rats exposed to long-term heat stress. Andrologia. 2014;47(9):1-7.

7. Snorek M, Hodyc D, Sedivý V, Durišová J, Skoumalová A, Wilhelm J, et al. Short-term fasting reduces the extent of myocardial infarction and incidence of reperfusion arrhythmias in rats. Physiological research. 2012;61(6):567-74.

8. Longo VD, Mattson MP. Fasting: Molecular mechanisms and clinical applications. Cell Metabolism. 2013;19(2):181-92.

9. Hill NR, Samuel FT, Jason LO, Jennifer AH, Christopher AO, Daniel SL, et al. Global prevalence of chronic kidney disease- A Systematic Review and Meta-Analysis. PLoS ONE. 2016;11(7).

10. Omolaso BO, Akanbi CO, Akintayo CO, Oluwe FS. Evaluation of the effects of fasting on fertility in adult male wistar rats. IOSR Journal of Pharmacy and Biological Sciences. 2018;3(4):12-5.

11. Agustina DIV. Pengaruh puasa 30 hari terhadap kadar glukosa darah pada masyarakat usia lebih dari atau sama dengan 40 tahun (studi in vivo Rattus Novergicus). Vol. 3. Akademi Analis Kesehatan Malang; 2011.

12. World Health Organization (WHO). WHO laboratory manual for the examination of human semen and sperm-cervical mucus interaction. Cambridge, UK: Cambridge University Press; 2010.

13. Jalili C, Ahmadi S, Roshankhah S, Salahshoor MR. Effect of genistein on reproductive parameter and serum nitric oxide levels in morphine-treated mice. International journal of reproductive biomedicine (Yazd, Iran). 2015;14(2):95-102.

14. Munandar A, Nurcahyani N, Hendri B. Pengaruh kebisingan terhadap kualitas spermatozoa mencit (Mus musculus L.). In: Seminar Nasional Sains \& Teknologi V. Lampung; 2013. p. 1-9.

15. Diartha IWW, Sudatri NW, Setyawati I. Pengaruh pemberian ekstrak Tauge ditambah madu terhadap kualitas spermatozoa mencit jantan (Mus Musculus L.). Jurnal Simbiosis. 2016;4(1):1-5.

16. Fitria L, Mulyati, Tiraya CM, Budi AS. Profil reproduksi jantan tikus (Rattus norvegicus Berkenhout, 1769) galur wistar stadia muda, pradewasa, dan dewasa. Jurnal Biologi Papua. 2015;7(1):29-36.

17. Ghanbari M, Mortazavi SB, Khavanin A, Khazaei M. Simultaneous effects of exposure to microwaves and noise on male rats sperm parameters and total antioxidant capacity. Health Scope. 2012;(4):178-84.

18. Wu A, Wan F, Sun X, Liu Y. Effects of dietary restriction on growth, neurobehavior, and reproduction in developing Kunmin mice. Toxicological Sciences: An Official Journal of the Society of Toxicology. 2002;70(2):23844.

19. Roushandeh AM, Salehi I, Mortazavi M. Protective effects of restricted diet and antioxidants on testis tissue in rats fed with high-fat diet. Iranian biomedical journal. 2015;19(2):96-101.

20. Agarwal A, Sekhon LH. The role of antioxidant therapy in the treatment of male infertility. Human Fertility. 2010;13:217-25.

21. Rahim R, Juniarto AZ. Pengaruh pemberian minyak jinten hitam (Nigella sativa) terhadap motilitas spermatozoa mencit diabetes melitus yang diinduksi Aloksan. Semarang; 2008. 
22. Faranita OV. Kualitas spermatozoa pada tikus wistar jantan diabetes melitus. Semarang; 2009.

23. Bashandy AES. Effect of fixed oil of Nigella Sativa on male fertility in normal and hyperlipidemic rats. International Journal of Pharmacology. 2007;3(1):27-33. 